\title{
数值計算による矩形面と全身との形態係数の評価 \\ ANGLE FACTORS BETWEEN HUMAN BODY AND RECTANGULAR PLANES CALCULATED BY A NUMERICAL MODEL
}

\author{
尾関義一*，小西正哲**，成田千恵***，田辺新一**** \\ Yoshiichi OZEKI, Masaaki KONISHI, Chie NARITA \\ and Shin-ichi TANABE
}

\begin{abstract}
Angle factors between human body and rectangular planes are calculated by a numerical model. Present method, which is applied for predicting the thermal radiation field in a space, is based on a numerical integration method proposed in the previous authors' paper. To confirm the validity of this method, predicted angle factors for both standing and seated persons are compared with those by the experimental method. It was found that predicted figures are met quite well with those by the subjective experiments. From previous results, however, significant difference was found in angle factors between the human body and the front floor. In addition, angle factors between each body surface and rectangular planes including the floor were also investigated.
\end{abstract}

Keywords : numerical simulation, angle factor, effective radiation area, rectangular plane, human body, standing and seated postures 数值計算, 形態係数, 有効放射面積, 矩形面, 人体, 立位・椅座位

\section{1.はじめに}

居室, 車室, アトリウムの内部では, 不均一な温熱環境が生じて いることがある. 本研究では,このような空間での人体の熱的快適 性を定量的に評価する数值シミュレーション手法,及び温冷感指標 を開発することを最終の目的としている. 別報1では，人体形状に 応じた有効放射面積及び投影面積を,数値シミュレーションにより 精度良く予測するための計算手法を提案し，その有効性を既往の測 定結果との比較により示した.これにより，人体形状に応じた日射 取得熱量分布を精度良く予測することが可能となった. 本報では， 人体表面と周囲空間との間の放射熱授受を算出する場合に必要とな る形態係数を, 文献2)に示す著者らの数值積分法により求め, その 精度をFangerらの被験者測定結果 ${ }^{3)}$, 土川らの被験者測定結果 ${ }^{4)}$ と の比較により検討した. 本手法により，人体放熱性状に大きな影響 を与える周囲空間との放射熱授受を,様々な人体形状に対して精度 良く予測することが可能となる.

\section{2. 形態係数の算出法に関する既往の研究}

人体と周囲空間との間の形態係数の算出には，写真撮影法 ${ }^{33,4) な ~}$ どによる実験的な手法が用いられている. Fanger ら゙は，男女各 10 人の立位・椅座位および着衣の有無を対象とし, 測定時の煩雑さ
を改善して合計78種類の投影面積を測定し,矩形面との間の形態係 数を評価している，土川ら ${ }^{4)}$ は，体型・体格の異なる青年男性 3 名 を対象として，立位・椅座位の姿勢条件，着衣・裸体の着衣条件で の人体と矩形面との間の形態係数を写真撮影法により評価している. 一般に, 写真撮影法などの実験的手法は貴重なデ一タを提供するが, 取り扱いが煩雑となるため, 様々な姿勢, 体型, 部位別評価, さらに は周囲空間の形状に応じた詳細な検討に対し多くの時間を要する.

山畸ら5)は, 立位姿勢の人体を計測して人体形状モデルを作成し, 壁面上の点との間の形態係数を求めている.さらに, 人体形状を近 似する直方体形状を提案している．宮崎ら ${ }^{61}$ は，立位・椅座位の姿 勢に対し, 円筒の組み合わせにより人体形状モテルを作成し，モン テカルロ法により矩形面との間の形態係数を評価しているが, 既往 の測定結果 ${ }^{3)}$ との対応に十分な検討がなされていない.土川ら”は, 人体を形状モデルで近似した場合の壁面との間の形態倸数を求め る, 錐面積分に基づく数值計算手法を提案しているが, 具体的な検 討はされていない．鈴木ら ${ }^{8}$ は，立位姿勢の 2 名の人体を計測して 人体形状モデルを作成し,矩形面との間の形態保数を立体角投射法 及び写真撮影法により算出し比較している.このように既往の研究 において, 人体形状に応じた周囲空間との間の形態係数を数值シ ミュレーションにより詳細に検討した例は比較的少ない.

\footnotetext{
* 旭硝子侏中央研究所 主席研究買 - 工博

** 旭硝子(侏中央研究所 研究員

*** お茶の水女子大学大学院人間環境科学専攻 大学院生

**** 早稲田大学理工学部 助教授. 工博
}

Research Center, Asahi Glass Co., Ltd., Dr. Eng.

Research Center, Asahi Glass Co., Ltd.

Graduate Student, Dept. of Human Env. Eng., Ochanomizu Univ.

Assoc. Prof., Dept. of Architecture, Waseda Univ., Dr. Eng. 


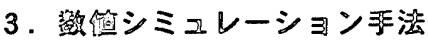

\section{3-1 人位砷状}

人体を形状モデルにより近似し，人体表面における放射・対流熱 輸送を解析する場合,及び数值計算により壁面との形態係数を算出 する場合には, 人体形状及び形状モデルの表面要素分割の影踷を受 ける. 人体形状を模した形状モデルについては, 有効放射面穦及び 形態係数を算出するためのモデル5),6),8)，日射熱取得解析と対流・放 射連成シミュレーションにより, 人体放熱特性を解析するためのモ デル ${ }^{9), 10)}$ ，人体内部の熱移動を解析するためのモデル ${ }^{11)}$ な゙数多く 提案されている. 本研究では，不均一睘境下における人体部位別放 熱珄状を精度良く捉えるために，耳，累，口，手の指，足の指などの 人体表面の凹凸を詳細に表現した 3 次元モデルを採用するま1).本報 で满討した立位, 椅座位の人体形状を図 1 , 本モデルの身長, 体表 面竇を表 1 に示す. 本モテルの身長は，既往の研究で用いられた数 値より僅かに高いが，身長，表面積ともにFangerらの結果に近い。 本研究では, 著者らが提案した日射熱取得解析 ${ }^{12)}$ と対流・放射連成 シミュレーション13)との連成を容易にするため, 人体の表面形状を すべて微小四角形で表現し，これを計算最小単位とする. 本モデル では立位,椅座位ともに 4396 の微小四角形に分割した。

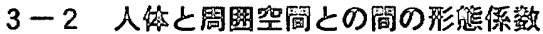

人体と周囲空間との間の形態倸数 $F_{p-A 2}$ は, 人体の有効放射面積 $A_{e f f}$, 人体微小面 $i$ と周囲空間微小面 $j$ との形態係数 $F_{i j}$, 人体微小面 $i$ の面積 $A_{i}$ を用いて(1)式で求められる ${ }^{3)}$.

$$
\mathbb{F}_{p-A 2}=\sum_{i} \mathbb{A}_{i} \sum_{j} \mathbb{F}_{i j} / \mathbb{A}_{\text {eff }}
$$

人体微小面 $i$ と周囲空間微小面 $j$ との形態係数 $F_{i j}$ は, 文献 2)で著 者らが提案した数值穞分法により,微小面間の遮蔽を考虑して算出 する. 形態係数算出アルゴリズムは任意形状に対応するため, 様々 な人体形状及び空間形状に応じた形態係数を容易に算出することが 可能となる.

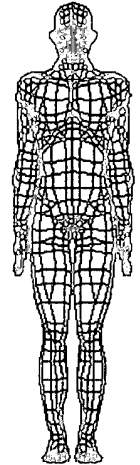

(a)立位

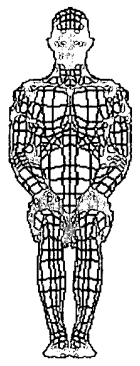

(b)椅座位

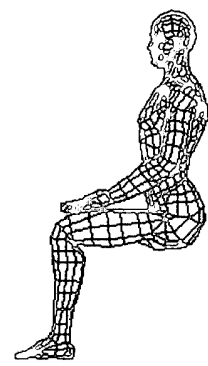

図 1. 解析に用いた人体形状

表 1 人体形状デー夕

\begin{tabular}{|c|c|c|c|c|c|}
\hline & 动鿬案 & Fanger3) & t川14 & 舁绿6) & 鲳9) \\
\hline 毁言 $(m)$ & 1.75 & 1.72 & 1.70 & 1.71 & 1.65 \\
\hline 新面管 $\left(\mathrm{m}^{2}\right)$ & 1.72 & 1.78 & 1.69 & 1.58 & 1.70 \\
\hline
\end{tabular}

*Fanger の結果は男女各 10 名の平均值

\#土川の結果は青年男性 3 名の平均值

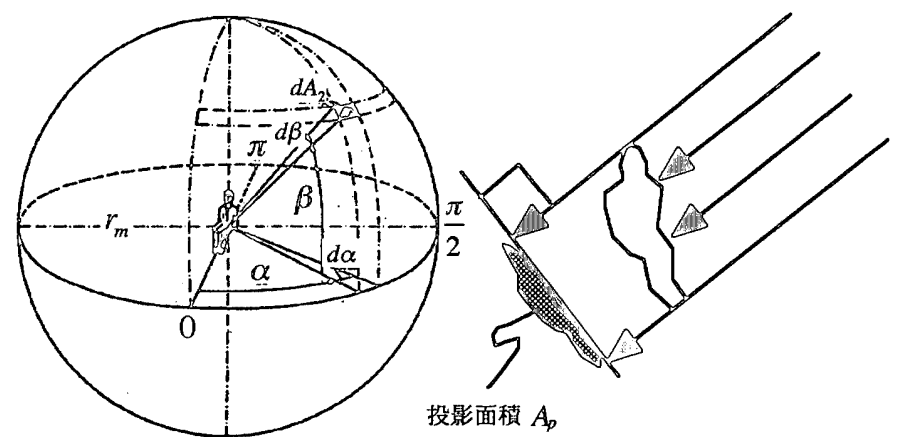

図 2. 有効放射面䅧算出のための閉空間 ${ }^{3)}$ 図3. 平行光線に対する人体の投影面穦

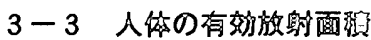

人体の有効放射面樻 $A_{\text {eff }}$ は, 形態係数の相反則及び図 2 に示す半 径 $r_{m}$ の球から人体を見た形態係数 $F_{A 2-p}$ を用いて(2)式で求められる.

$$
A_{\text {eff }}=\Delta \pi \pi r_{m}^{2} \mathbb{F}_{A 2-p}
$$

球から人体を見た形態係数 $F_{A 2-p}$ を図 3 に示すような平行光線に対 する人体の投影面積 $A_{p}$ で評価すると, 人体の有効放射面樻 $A_{\text {eff }}$ は球 座標を用いた(3)式で算出できる ${ }^{3)}$.

$$
A_{e f f}=\frac{4^{2}}{\pi} \int_{\alpha=0}^{\alpha=\pi} \int_{\beta=0}^{\beta=\frac{\pi}{2}} A_{p} \cos \beta d \beta d \alpha
$$

有効放射面穞を(3)式で算出するためには, 図 3 に示した平行光線 に対する人体の投影面積 $A_{p}$ を求める必要がある.この投影面積は， 人体表面において平行光線を受ける部位を投影面に対し射影した面 讂に等しい.この面積を, 文献 12)で著者らが提案した日射熱取得 シミュレーション手法を応用して算出する ${ }^{1)}$. 日射熱取得アルゴリ ズムは任意の室内形状に対応するため, 人体の梯々な形状に応じた 投影面樻を容易に算出することが可能となる.

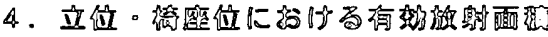

立位・椅座位での全身と周囲空間との間の形態係数を算出するた めには，有效放射面稳を予め算出しておく必要がある. 本研究で は, 有効放射面積を算出するための(3)式を数值䅡分で評価する. 積 分点は $\alpha$ (方位角)方向に 13 点, $\beta$ (高度)方向に 7 点設定する. 人体 を図 2 に示す球の中心に設置し, 人体正面を方位角 $0^{\circ}$ とする. 球の 表面上に設定した各積分点と球の中心を結ぶ線分に平行な光線に対 し, 人体の投影面積 $A_{p}$ を算出する. 算出された有効放射面積 $A_{\text {eff }}$ 及 び有効放射面積率 $f_{\text {eff }}$ 注2)を表 2 に示す. 立位の有効放射面䅡及び有

表 2 有効放射面積及び有効放射面䅡率 (a)立位

\begin{tabular}{c|c|c|c|c}
\hline & 本研究 & Fanger $^{3)}$ & 土川 ${ }^{4)}$ & 宮崎 $^{6)}$ \\
\hline$A_{\text {eff }}\left(\mathrm{m}^{2}\right)$ & 1.276 & 1.262 & 1.312 & 1.317 \\
\hline$f_{\text {eff }}(-)$ & 0.744 & $\begin{array}{l}0.725 \\
\pm 0.013\end{array}$ & $\begin{array}{c}0.803 \\
\pm 0.005\end{array}$ & 0.834 \\
\hline
\end{tabular}

(b)椅座位

\begin{tabular}{c|c|c|c|c}
\hline & 本研究 & Fanger $^{3)}$ & 土川 ${ }^{4)}$ & 宮崎 $^{6)}$ \\
\hline$A_{\text {eff }}\left(\mathrm{m}^{\mathrm{i}}\right)$ & 1.176 & 1.211 & 1.214 & 1.224 \\
\hline$f_{\text {eff }}(-)$ & 0.691 & $\begin{array}{l}0.696 \\
\pm 0.017\end{array}$ & $\begin{array}{l}0.740 \\
\pm 0.012\end{array}$ & 0.775 \\
\hline
\end{tabular}

*Fanger, 土川の結果は裀体時 
効放射面積率は椅座位よりやや大きく算出されている.これは立位 に比べて椅座位姿勢は周囲との放射熱授受に対し，約 $5 \%$ の有効放 射面積の減少があることを示す．立位・椅座位の結果と Fanger ら の被験者実測結果を比較すると，その差は $2 \%$ 以下となった.

\section{5. 立位・椅座位と矩形面との形態係数一人体と矩形面との} 茞離が 7 mの場合一

\section{5-1 算出条件}

既報 ${ }^{2)}$ で示した形龍係数の算出法が，複雑な人体形状と周囲空間 を対象としても十分な予測精度を有することを確認するために, 全 身と様々な矩形面との形態係数を算出し, Fanger の測定結果と比 較する. 矩形面は，図4に示すように立位の人体形状に対し 3 種類 (前壁 $\mathrm{A}$, 側壁 $\mathrm{B}$, 天井 $\mathrm{C}$ ), 椅座位の人体形状に対し 6 種類（前壁 $\mathrm{A}$, 側壁前部 $\mathrm{B}$, 天井前部 $\mathrm{C}$, 後壁 $\mathrm{D}$, 側壁後部 $\mathrm{E}$, 天井後部 $\mathrm{F}$ ) 設定する. 各矩形面と人体との距離 $c$ は Fanger の測定条件と同じ $7.0 \mathrm{~m}$ とす る. また，矩形面の縦横の長さはそれぞれ，

$$
\begin{aligned}
a / c= & 0.2,0.4,0.6,0.8,1.0,1.5,2.0,3.0,5.0 \text { の } 9 \text { 通り, } \\
b / c= & =.2,0.4,0.6,0.8,1.0,1.2,1.4,1.6,1.8, \\
& 2.0,2.5,3.0,4.0,5.0,6.0,7.0,8.0,9.0,10.0 \text { の } 19 \text { 通り, }
\end{aligned}
$$

合計 171 通りとした．全身と各矩形面との形態係数を(1)式で算出 する際，矩形面を一辺が $0.7 \mathrm{~m}$ の正方形に分割し, 人体を構成する 微小四角形間の遮蔽を考慮する注3)。

\section{5-2 計算結果・考察}

立位・椅座位の人体形状に対し，得られた形態係数をそれぞれ図 5-1, 図 5-2 に示す. 図 5-1, 図 5-2 にはFanger の測定結果も合わ せて示す. Fangerらの形態係数と対比して得られた，原点を通る 回帰式の傾き(回帰係数),奇与率(相関係数の 2 乗: $\mathrm{R}^{2}$ )を表 3 に示す.

立位・椅座位ともに, $b / c$ の增加に伴い全身と矩形面との間の形 態係数は, 単調増加の傾向を示す. $b / c$ の小さい領域では, 形態係 数が大きく変化し, $b / c$ の大きい領域ではほぼ一定となる.

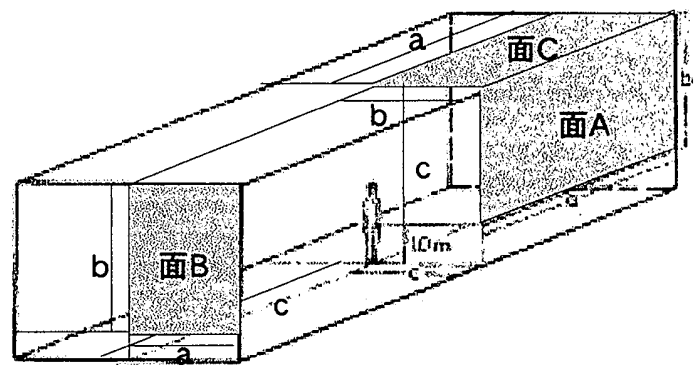

(a)立位

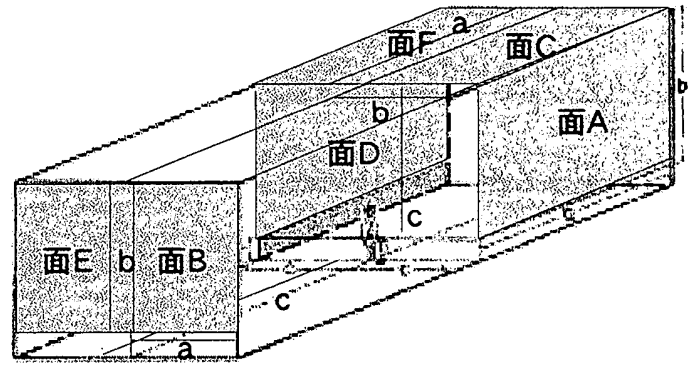

(b)椅座位

図 4. 人体と矩形面との間の形態係数の検討 ${ }^{3)}$

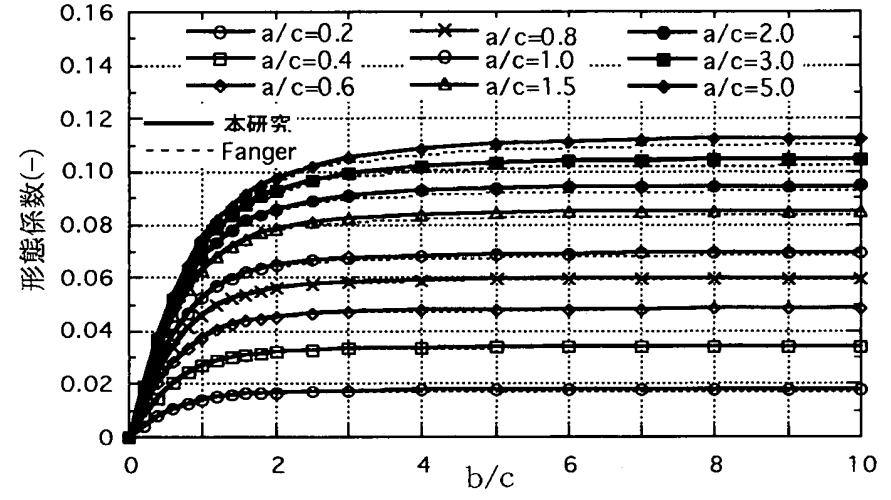

$\mathrm{A}$-前壁・立位

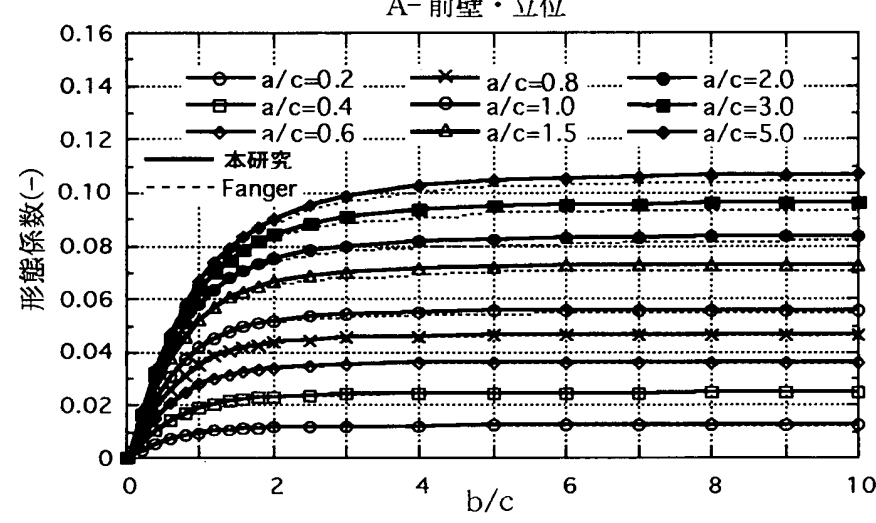

B- 側壁・立位

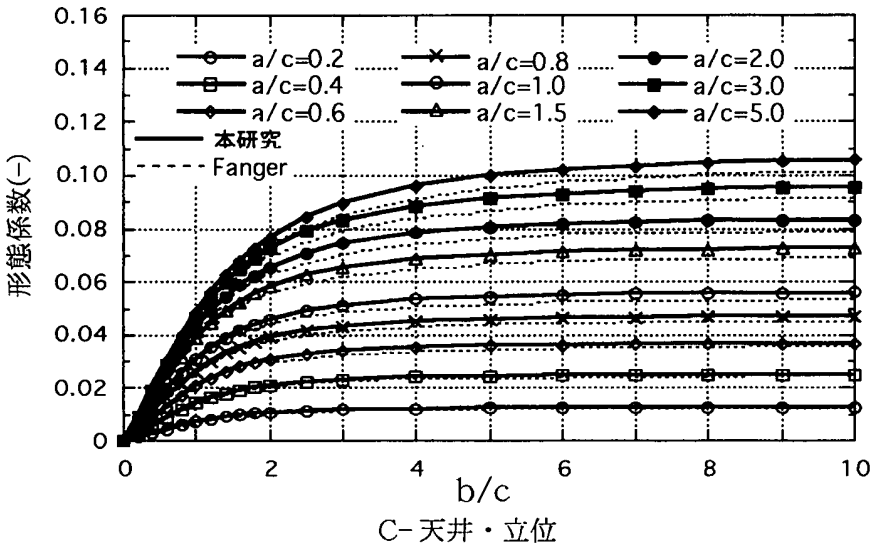

図 5-1. 人体と矩形面との間の形態係数(立位, $\mathrm{c}=7$ )

立位においてFangerの測定結果と比較すると，各矩形面に対し $a / c$ が小さい領域では良く一致している. $a / c$ が大きい領域では, 僅かな差異が見られるケースがあるものの,全体的に既往研究と良 く対応する．椅座位においてFangerの測定結果と比較すると，人 体に対し前方に位置する矩形面 $A, B, C$ C゙はほとんど一致した. 後方 に位置する矩形面 D,E,Fでは, $\boldsymbol{a} / \boldsymbol{c}$ が大きい領域で測定結果よりや や大きく算出された．腰の曲计角度, 臂部, 背中の形状などの僅か な差異が現われたためと思われる. 表 3 に示す回帰係数及び寄与率 から，立位・椅座位の予測結果とFangerの測定結果の差異は最大 で約 4\% 以下で，人体形状は異なるが十分な精度で一致している.

全身と矩形面との間の形態係数の算出において, Fangerは平行 光線を用いているのに対し ${ }^{3)}$, 本報では立体角を用いている. 立位・ 椅座位の形態保数の予測結果が測定結果に良く対応していることか ら, 人体から $7 \mathrm{~m}$ 程度離れた矩形面を対象とした形態係数の評価に 関し，算出法(平行光線，立体角)による明らかな差異はない注4)。こ れは土川らの結果とも対応している4). 

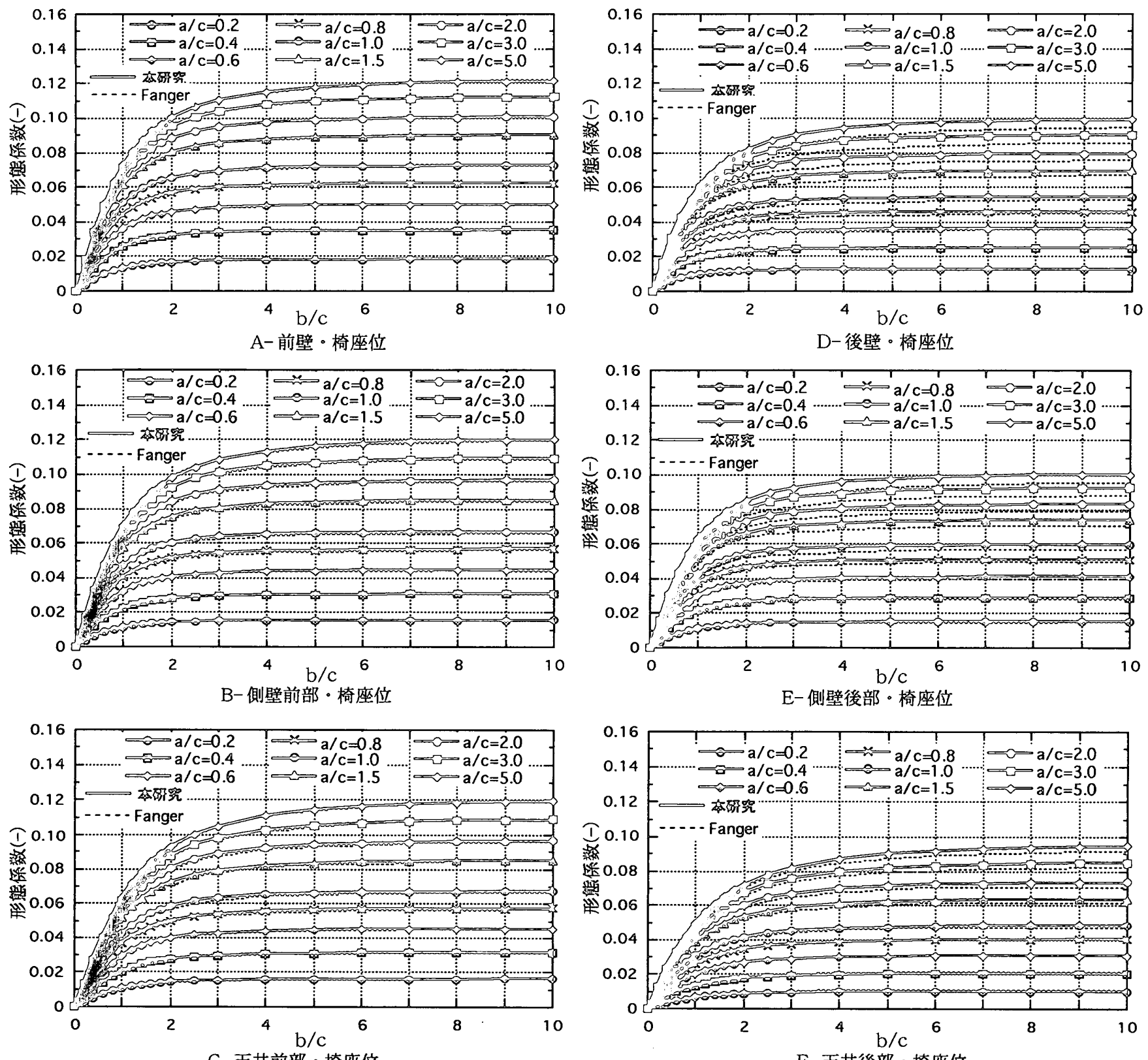

図 5-2. 人体と矩形面との間の形態係数(椅座位, $c=7$ )

(a)立位

\begin{tabular}{c|c|c|c}
\hline 壁面 & 前壁 & 側壁 & 天井 \\
\hline 回尖係数 & 0.992 & 0.989 & 0.963 \\
\hline 寄与率 & 0.999 & 0.994 & 0.999 \\
\hline
\end{tabular}

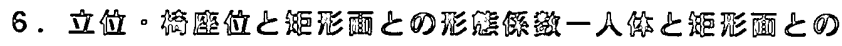
距的 $2 \mathrm{~m}$ 以下の踢合一

\section{6-1 定出终仵}

人体と各矩形面との距離を $7 \mathrm{~m}$ とした場合の形態俰数に関し, Fangerによる測定結果と予測結果は十分な精度で対応した.一方, 土川らは，人体と各矩形面との距離が $1 \mathrm{~m}$ 以下となる場合の形態係 数に関し，算出法(平行光線, 立体角)による差異が生じることを指 摘している ${ }^{4)}$. 本手法で予測した形態保数がこのような場合でも十 分な䋨度を有することを示すために，予測した形態係数と土川らの (b)椅座位

\begin{tabular}{|c|c|c|c|c|c|c|}
\hline 壁面 & 前壁 & 則壁前部 & 天井前部 & 後壁 & 則壁後部 & 厌井後部 \\
\hline 帯係 & 1.006 & 0.993 & 0.993 & 0.959 & 0.958 & 0.986 \\
\hline 与率 & 0.999 & 0.999 & 0.999 & 0.999 & 0.999 & 0.998 \\
\hline
\end{tabular}

測定結果 4),14)を比較する. 各矩形面との距離 $c$ は，土川らの測定条 件と同じ $2.0 \mathrm{~m}$ 以下とした. 矩形面は, 図6に示すように立位の人 体形状に対し 3 種類（前照 $\mathrm{A}$, 側壁 $\mathrm{B}$, 床 $\mathrm{E}$ ), 椅座位の人体形状に 対し 3 種穎（側照 $\mathrm{C}$, 後壁 $\mathrm{D}$, 床 $\mathrm{F}$ ）設定した.

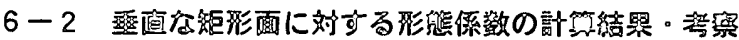

立位・椅座位の人体形状に対し，得られた形態係数を図 6 に示す. 図6にはFanger及び土川らの測定結果も合わせて示す.立位の場合， 矩形面 $\mathrm{A}$ (前壁)， $\mathrm{B}$ (側壁)に対し $\mathrm{c}=2$ として予測した形態係数は, 


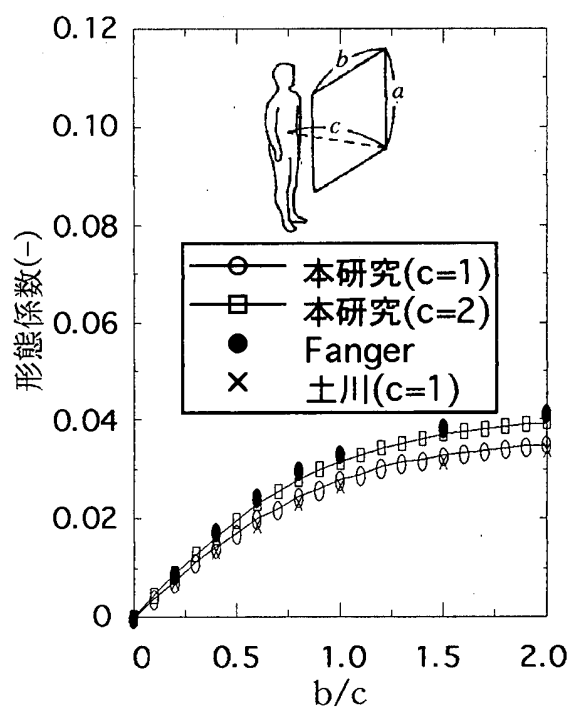

$A$ - 前壁・立位 $(\mathrm{a} / \mathrm{c}=0.5)$

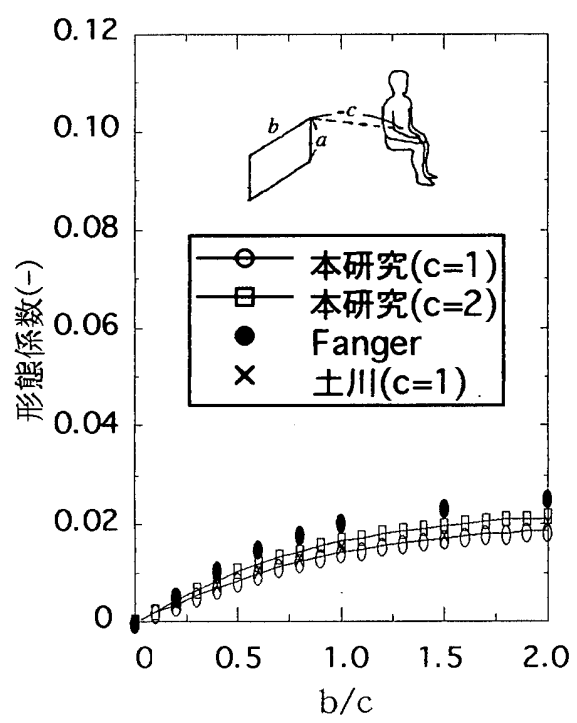

D- 後壁・椅座位 $(\mathrm{a} / \mathrm{c}=0.3)$

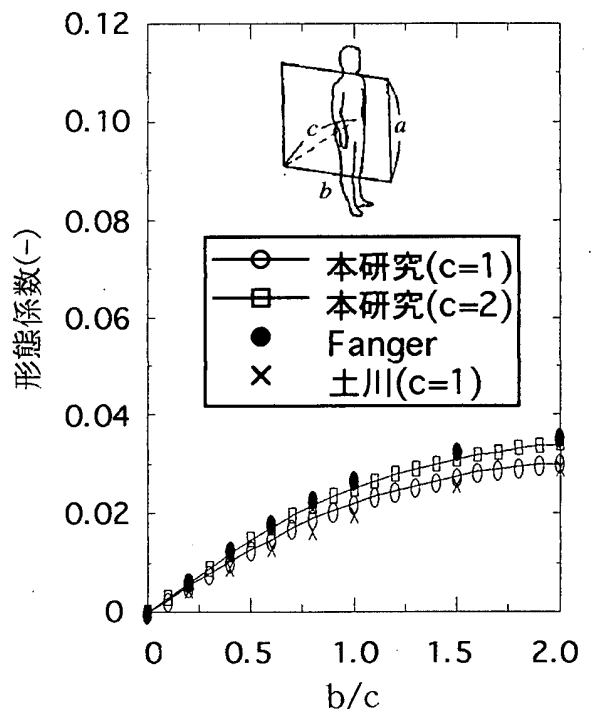

$\mathrm{B}-$ 側壁・立位 $(\mathrm{a} / \mathrm{c}=0.5)$

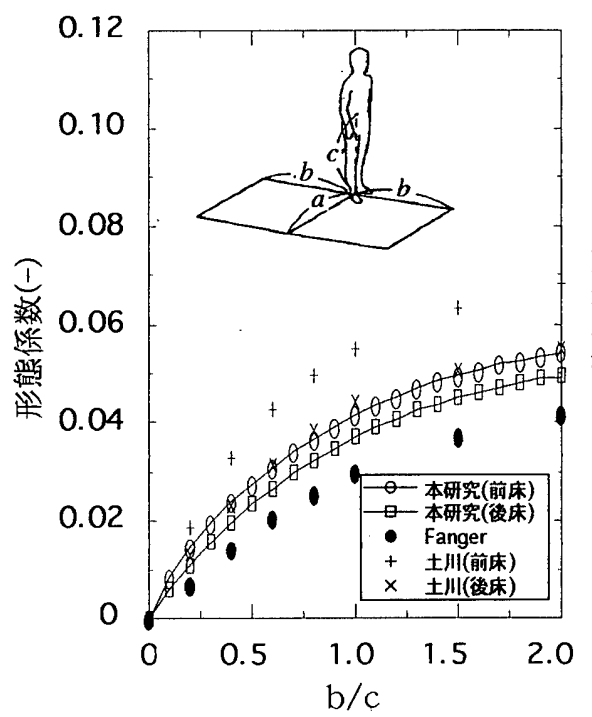

$\mathrm{E}$-床・立位 $(\mathrm{a} / \mathrm{c}=1)^{\text {注5) }}$

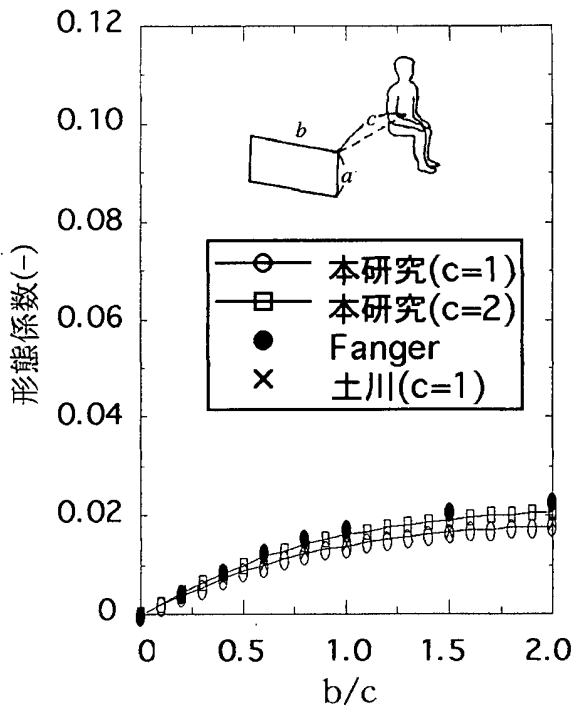

$\mathrm{C}-$ 側壁・椅座位 $(\mathrm{a} / \mathrm{c}=0.3)$

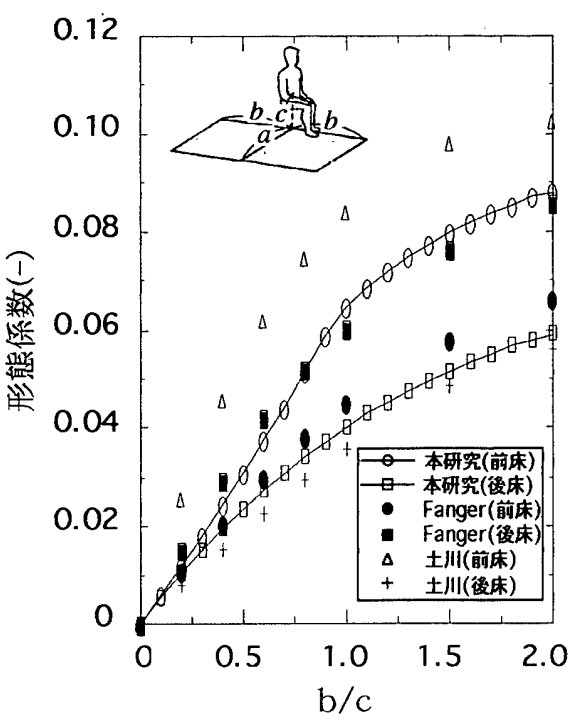

$\mathrm{F}$ 一床・椅座位 $(\mathrm{a} / \mathrm{c}=3.3)^{\text {注 } 5)}$

図 6. 人体と矩形面との間の形態係数(立位・椅座位 $)^{4)}$

Fanger の測定結果にその差が $6 \%$ 以内で一致し， $\mathrm{c}=1$ として予测し た形態係数は土川らの測定結果にその差が4\%以内で一致した注6). 各

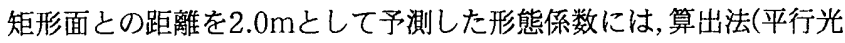
線,立体角)による差異涀られない.また, 各矩形面との距離を $1.0 \mathrm{~m}$ として予测した形態係数には, 算出法(平行光線,立体角)による差異 が見られ，同じ立体角法により得られた形態係数はほとんど一致し た. 椅座位の矩形面 C(側壁), $\mathrm{D}$ (後壁)の場合も，立位と同じ傾向が見 られる.土川らの実験の人体形状の詳細が不明であるため同一のモデ ルで比較はできていないが, 本手法で予測した形態係数は, 各矩形面 との距離が $2 \mathrm{~m}$ 以下の場合でも,十分な精度を有することが示された.

\section{6-3 床面に対する形態係数の計算結果・考察}

立位の場合, 図6.Eに示すように前床に対する形態係数は, 足先 により後床より大きく算出された. 椅座位の場合, 図6.Fに示すよ うに前床に対する形態係数は, 後床よりさらに大きく算出された. 前床に対する形態係数は, 足が置かれている $b / c$ が 1.0 付近まで大
きく変化し，それ以降は緩やかに変化する．立位・椅座位ともに, 後床に対する形態係数は土川らの結果にほほ対応したが, 前床に対 する形態倸数には差異が見られた．この原因について検討する.

\section{（1）姿勢に関する検討}

立位の人体形状の差異が予測結果に与える影響を検討する.検討は, 図 7 に示す猫背形状で行う注7). 前床, 後床に対する形態係数の予測結 果を図 8 に示す，前床，後床に対する形態係数の傾向に大きな差は見 られなかった. 図6.Eに示す形態係数と比較すると, 前床で最大 $3 \%$, 後床で最大 $7 \%$ 大きく算出された. 今回検討した人体形状の差異では, 前床, 後床に対する形態係数に与える影響が小さいことを確認した.

\section{（2）部位別の有効放射面積}

立位・椅座位の人体形状に対し, 人体各部位と床との間の形態係 数を算出した. 人体の部位分割は, 土川らと同様に図 9 に示す 4 部 位(head, body, arms, legs)とした ${ }^{14)}$. 形態係数を算出するために 
必要となる部位別の有効放射面樻の算出結果を表 4 に示す. 表 4 に は土川らの測定結果も合わせて示す.有効放射面積が最も大きい部 位は，立位・椅座位ともにbodyで全体の約 $40 \%$ を占める. 各部位 の有効放射面秝の比率を立位・椅座位で比較すると, head,bodyに は大きな差異は見られないが, arms, legsで立位・椅座位による差 が見られる．立位の土川らの部位別の有効放射面樻と比較すると， body,legs で約 20\%, head では約 30\%程小さく算出されている.

\section{（3）部位別の形態係䇺}

算出した部位別の形態係数を図 10-1,図 10-2に示す。立位にお いて,前壁(A)を対象とした部位別の形態係数を土川らの測定結果と 比較すると，図10-1に示すように headで有効放射面積の違いによ ると思われる最大約 $18 \%$ 差異が見られるが, 各グラフの傾向は類 似しており比較的良く対度している. また，全身の形態係数はほぼ 一致した. 本手法により部位別の形態係数を評価することが可能で あることを確認した. 次に, 前床(B)に対し土川らの測定結果と部位 別に比較すると, legs で最大約 $20 \%$, headで $50 \%$ 以上小さく算出
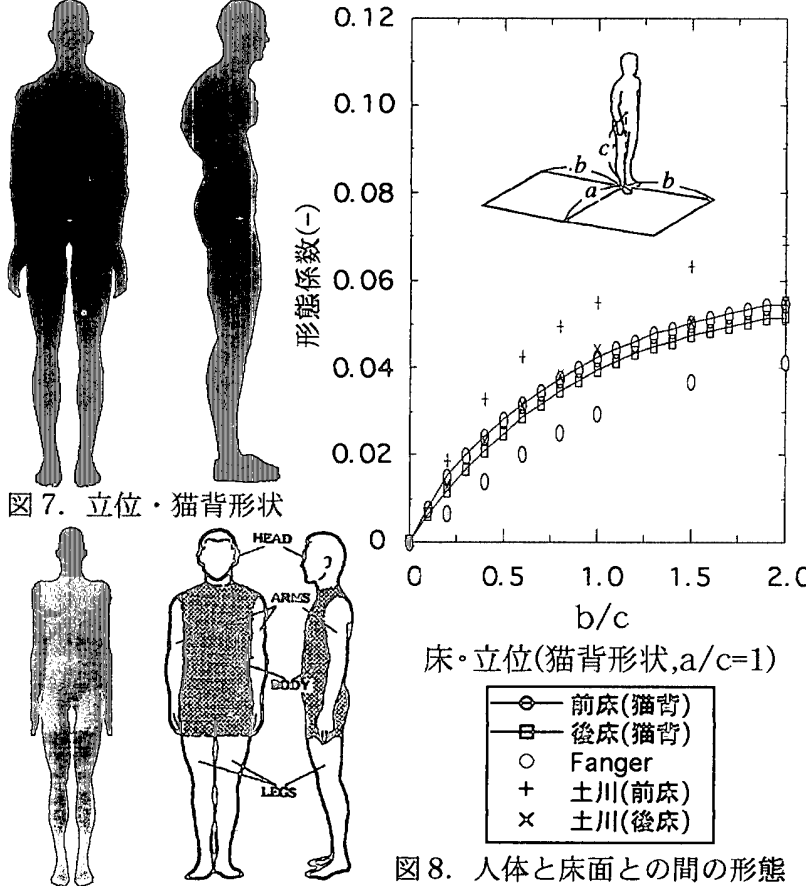

(a) 本研究

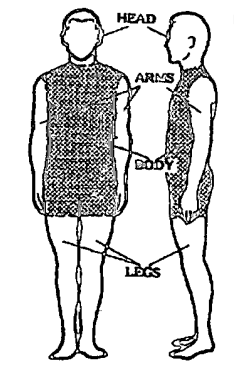

(b)土川
床。立位(猫背形状, $a / c=1$ )

\begin{tabular}{|c|c|}
\hline- & 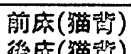 \\
\hline 专- & $\begin{array}{l}\text { 傩底 } \\
\text { Fano }\end{array}$ \\
\hline t & 土川( \\
\hline & \\
\hline
\end{tabular}

図 8. 人体と床面との間の形態 俰数(立位・猫背形状)

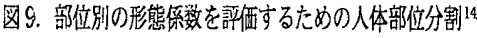

表 4 部位別の有効放射面䅡

(a)立位

\begin{tabular}{|c|c|c|c|c|c|}
\hline & HEAD & BODY & ARMS & LEGS & Whole Body \\
\hline 本研究 & $\begin{array}{l}0.12 \\
(9 \%)\end{array}$ & $\begin{array}{l}0.52 \\
(41 \%)\end{array}$ & $\begin{array}{l}0.26 \\
(20 \%)\end{array}$ & $\begin{array}{l}0.38 \\
(30 \%)\end{array}$ & $\begin{array}{c}1.28 \\
(100 \%)\end{array}$ \\
\hline 土川14) & $\begin{array}{r}0.17 \\
(12 \%)\end{array}$ & $\begin{array}{c}0.61 \\
(42 \%)\end{array}$ & $\begin{array}{c}0.25 \\
(17 \%)\end{array}$ & $\begin{array}{c}0.47 \\
(33 \%)\end{array}$ & $\begin{array}{l}1.48 \text { 注 } 8) \\
(100 \% \%)\end{array}$ \\
\hline
\end{tabular}

(b)椅座位

\begin{tabular}{c|c|c|c|c|c}
\hline & HEAD & BODY & ARMS & LEGS & Whole Body \\
\hline 办研究 & $\begin{array}{c}0.12 \\
(10 \%)\end{array}$ & $\begin{array}{l}0.45 \\
(39 \%)\end{array}$ & $\begin{array}{l}0.29 \\
(25 \%)\end{array}$ & $\begin{array}{c}0.31 \\
(26 \%)\end{array}$ & $\begin{array}{c}1.17 \\
(100 \%)\end{array}$ \\
\hline
\end{tabular}

*土川らの結果は，青年男性(身長: $1.68 \mathrm{~m}$, Dubois-Area:1.80 m)の測定結果
されている．これにより，全身では最大約 $25 \%$ 小さく算出された. この原因については明確ではないが, 矩形面に近い部位の有効放射 面積の差異が，形態倸数に顕著に現われたためと考えられる.

椅座位において, 前床(C), 後床(D)の部位別の形態係数を比較す る. 図10-2に示すようにarms,headでは形態保数に大きな差異が 生じない. bodyでは前床(C)に対する形態係数が, legsによる遮蔽 により後床(D)より最大約 30\%程小さく算出された. legsでは前床 (C)の形態係数が, 後床(D)より最大約 4 倍程大きく算出され，これ が全身の形態係数に大きな影響を与えている.

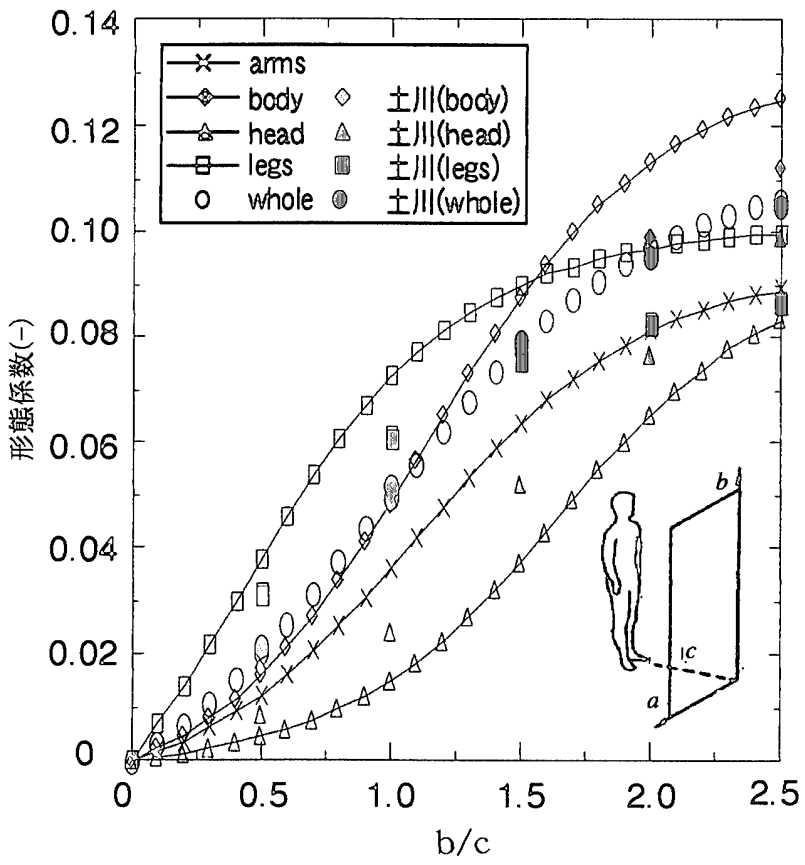

$\mathrm{A}-$ 前壁。立位 $(\mathrm{a} / \mathrm{c}=1, \mathrm{c}=1)$

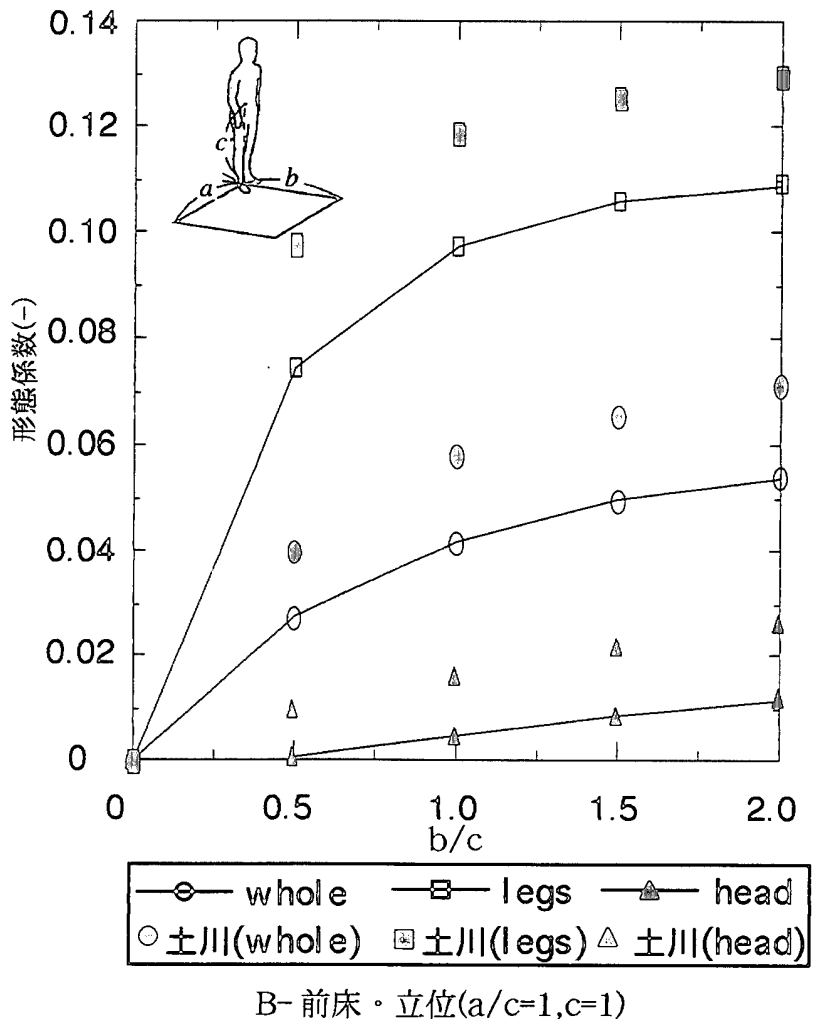

図 10-1. 人体と矩形面との間の部位別の形態係数(立位) ${ }^{14)}$ 


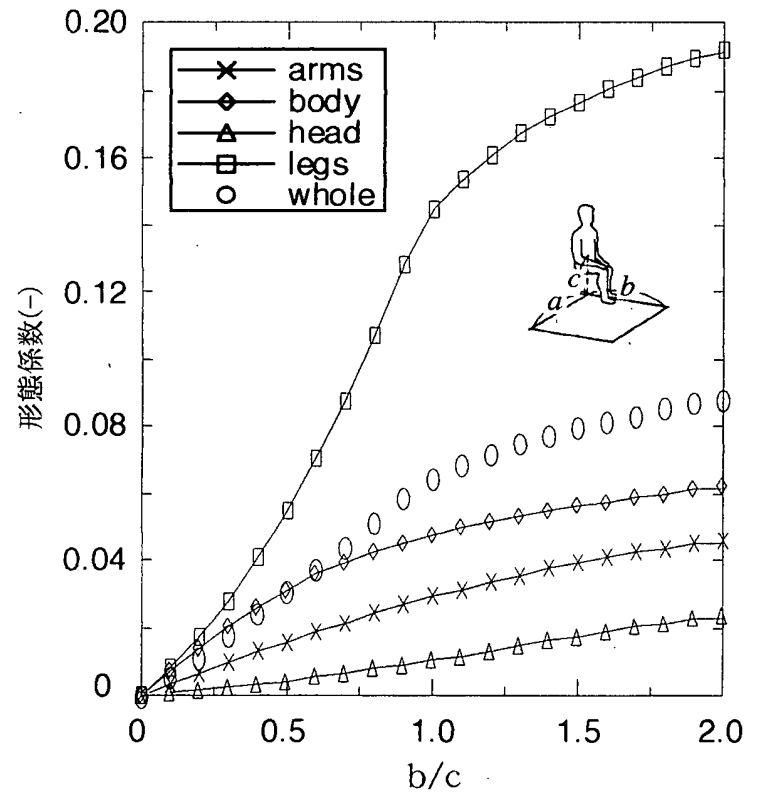

$\mathrm{C}$ - 前床・椅座位 $(\mathrm{a} / \mathrm{c}=3.3)$

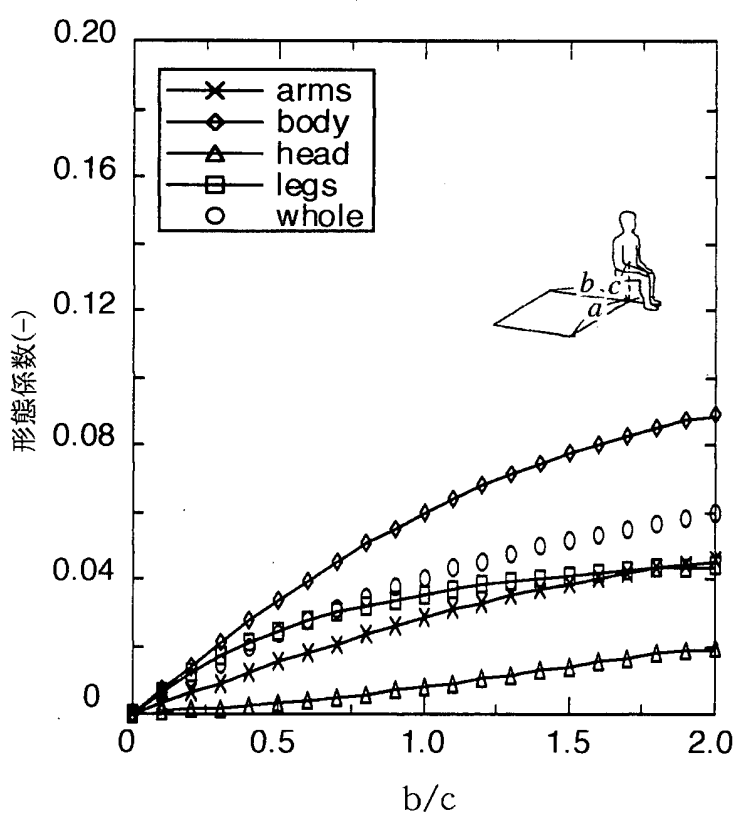

D- 後床・椅座位 $(\mathrm{a} / \mathrm{c}=3.3)$

図 10-2. 人体と床面との間の部位別の形態係数(椅座位)

\section{7.まとめ}

立位・椅座位の人体形状と周囲空間との間の形態係数を, 著者ら が提案した数值積分法により算出し, 既存の実験データとの比較検 討を行った. Fanger，土川らの実験における詳細な人体形状の入 手が困難なため人体形状は完全には一致していないが,以下の結論 が得られた。

(1)立位・椅座位に対する全身の形態係数を算出するために, 有効放 射面積及び有効放射面積率を算出した. Fangerらの測定結果との 差は $2 \%$ 以下となった。

(2)立位・椅座位について代表的な矩形面との間の形態係数を, 人体 と矩形面との距離をFangerの測定条件と同じ7mとして算出した. Fanger の測定結果と比較したところ，その差が $4 \%$ 以内で一致す る結果が得られた.

(3)立位・椅座位について代表的な矩形面との間の形態係数を, 人体 と矩形面との距離を土川らの測定条件と同じ $2 \mathrm{~m}$ 以下として算出し た.土川らの測定結果と比較したところ,床面を除いてその差が $4 \%$ 以内で一致する結果が得られた。

(4)床面との形態係数に関し, 立位の人体形状の差異及び立位・椅座 位における部位別の検討を行った. 今回検討した猫背形状などの人 体形状の差異では, 形態係数に与える影響が最大 $7 \%$ と小さいこと を確認した. 土川らが測定した前床に対する形態係数との差異は, 矩形面に近い部位の有効放射面䅡の差異が,形態係数に顕著に現わ れたためと考えられる。

以上の検討により，本モデを用いて，種々の人体形状に対する 全身, 部位別の形態係数の予測が, 工学的に十分な精度を持って可 能となった. また, 周囲空間との放射熱授受を人体形状に匛じて数 値計算により予測することが可能となった。

注䣋1)本人体モデルでは，姿勢，男女差，体格などを自由に設定しモデル化で きることに大きな特徴がある。

2)人体の有効放射面積 $A_{\text {eff }}$ を全身の体表面䅡 $A_{D u}$ で基簕化した指標 $\left(f_{e f f}=A_{e f f} / A_{D u}\right)$.
3)人体形状を構成する他の微小四角形により遮蔽されているか否かの判定は, 対象とする微小四角形と分割された矩形面の中心を結ぶ線分と，すべての微小 四角形との交差判定で行う.微小四角形と線分が交差する場合は完全に遮蔽す る，交差しない場合は全く遮蔽しない，微小四角形の辺上で交差する場合は $50 \%$ 遮蔽するとしている.

4)両者の手法の差異は, 人体に対するごく近傍の壁面などにおける形態係数に 現れる. 形態你数算出面が壁面などの有限範囲内に存在する場合には, 立体角 による算出法が舻密性を有する. 一方, 太陽からの直達日射の影響を想定した 場合，平行光線による算出法が適すると考えられる.

5)土川らと同様に, 足裏と接触している床面との形態係数は 1.0 とした ${ }^{14)}$. 6)各矩形面との距離を $2.0 \mathrm{~m}$ として予測した形態俰数と Fanger の测定結果と 対比して得られた，原点を通る回帰式の回帰係数は 1.060 , 寄与率は 0.991 で あった. また，各矩形面との距離を $1.0 \mathrm{~m}$ として予測した形態倸数と土川らの 測定結果と対比して得られた, 原点を通る回帰式の回帰保数注 0.960 , 寄与率 は 0.990 であった。

7)猫背形状の有效放射面積は $1.260 \mathrm{~m}^{2}$ である.

8)人体各部位の有効放射面積の合計は $1.50 \mathrm{~m}$ であり，全身に対し測定した有効 放射面䄼 1.44 mより大きい。 これは測定誤差及び部位の分割に起因すると考 察されている ${ }^{14)}$

\section{参考文献}

1)尾関義一，小西正哲，成田千恵，田辺新一：日射が温熱感に与える影響に関す る研究（その $1 〜 3)$, 日本建築学会大会学術講演梗概集, pp.381-386, 1998. 2)尾関義一, 斉藤恒洋,大杮聡: 複雑な内部形状を有する大規模メッシュ対応型 放射伝熱計算手法に関する研究, 空気調和・衛生工学会論文集, No.62, pp.101-110, 1996.

3)Fanger P.O., Angelius $O$. and Jensen P.K.:Radiation Data for the Human Body, ASHRAE Transactions, Vol.76- I] , pp.338-373, 1970.

4)土川忠浩, 小林陽太郎, 寚越哲美, 三輪恵美, 藏澄美仁, 平山慶太郎 : 実測に よる人体の有効放射面積および人体と矩形面との間の形態俰数に関する研究, 日本建築学会計画系諭文報告集，第 388 号, pp.48-59, 1988. 
5)山埼均, 真鍋正規, 辛島俊治 : 人体モデルの形態俰数一壁面から見た場合一, 日本建築学会大会学術嵒演梗概集, pp.157-158, 1983.

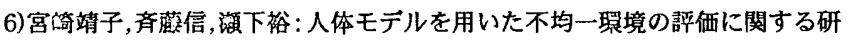
究, 人間と生活䍗境, No.1, pp.92-100, 1995.

7)土川忠浩, 堀越哲美 : 人体形状モデルを用いた人体と空間との放射熱授受に 関する研究(第 1 報)有效放射面積および形態係数の算出理論と人体表面 3 次元 座標测定法, 日本建学学会大会学術塕演梗概集, pp.355-356, 1996.

8)鈴不健次，垣鎊直：人体形状モデルの妥当性の検討，日本建築学会東海支部 研究報告集第 35 号, pp.529-532, 1997.

9)曾繁，村上周三，加藤信介：人体放熱に関するCFD・放射・湿気輸送連成解 析 , 第 11 回效值流体力学シンポジウム, pp.283-284, 1997.

10)岩本静男 : 人体放熱モデルによる床暖房空内環境の数值予測, 第19回人間生活環境系シンポジウム, pp.94-97, 1995.

11)横山真太郎,角田直人，富樫貴子，濱田䐀弘，中村真人，落藤澄 : 部位別特性を考 窖した人体の定常熱移動モデルの開発とその応用, 空気調和・衛生工学会学術 丵演会讙演論文集 , pp.513-516, 1997.

12)尾関義一, 尊田嘉之, 平松徹也, 斉藤恒洋, 大柿貪 : 放射・対流連成解析のた めの複雑な内部形状,大規模メッシュに対応する日射熱取得計算手㳎に関する 研究, 空気調和・簿生工学会論文集, No.66, pp.1-11, 1997.

13)尾関義一, 加藤信介, 村上周三: 実险用実大アトリウム内の熱伝達・気流性 状に関するCFD解析(その 1 )CFD・2波長放射連成シミュレーションにおける サッシュのモデリングに関する研究, 空気調和・衛生工学会論文集, No.68, pp.65-75, 1998.

14)土川忠浩, 堀越哲美, 近藤恵美, 藏澄美仁, 平山慶太郎, 小林陽太郎 : 実測に よる人体の有效放射面䅡および人体と矩形面との間の形態係效に関する研究(そ の2), 日本建築学会計画系論文報告集，第 428 号, pp.67-75, 1991.

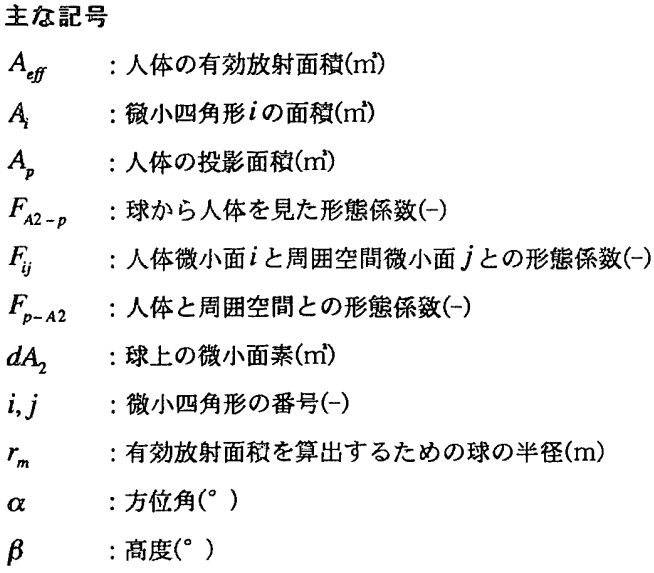

（1998年 7 月 10 日原稿受理，1999年 2 月 26 日操用決定） 